\title{
Changes in precipitation extremes in Brazil (Paraná River Basin)
}

\author{
Leandro Zandonadi • Fiorella Acquaotta • \\ Simona Fratianni • João Afonso Zavattini
}

Received: 31 July 2014 / Accepted: 23 January 2015 / Published online: 8 February 2015

(C) Springer-Verlag Wien 2015

\begin{abstract}
This research was aimed at addressing aspects related to variation in the amount of precipitation during the period from 1986 to 2011 in the Paraná River Hydrographical Basin, Brazil, for 32 meteorological stations using 11 climate indices created by the ETCCDI (Expert Team, ET, on Climate Change Detection and Indices, ETCC DI). The daily rainfall data were organized in spreadsheets, which were subjected to an intense quality control and an accurate historical research. For each pluviometric index, we have estimated the trends and the statistical significant of the slopes have been calculated. The results confirm that an increase in total precipitation in almost all analyzed stations was registered, and the extreme precipitations were the main contributors to such additions. In fact, the significant increase in total annual rainfall in north-central sector of the basin are related to higher rates of heavy rain, mainly above 95 th percentile, as well as to the highest event of rainfall above $10 \mathrm{~mm}$. Instead the northern part of the region, showed declining trends of extreme rainfall, caused mainly by the reduction in the rainfall occurrences over 95 th percentile. In order to evaluate the impact that the increasing extreme rainfall may cause in large urban centers, we have investigated the data of two municipalities (Curitiba, PR and Goiânia, GO-Brazil), where
\end{abstract}

\footnotetext{
L. Zandonadi $\cdot$ J. A. Zavattini

Programa de Pós-Graduação em Geografia, Universidade Estadual Paulista - UNESP, Instituto de Geociências e Ciências Exatas, Avenida 24 A, número 1515, 13506-900 Rio Claro, São Paulo, Brazil

F. Acquaotta $\cdot$ S. Fratianni

Dipartimento di Scienze della Terra, Università di Torino, Via

Valperga Caluso 35, 10125 Torino, Italy

S. Fratianni $(\varangle)$

Centro di Ricerca sui Rischi Naturali in Ambiente Montano e

Collinare (NatRisk), via Leonardo da Vinci 4, 10095 Grugliasco, TO, Italy

e-mail: simona.fratianni@unito.it
}

the positive trend can cause inconvenience to the population (floods and inundations) suggesting, at least, the need of implementation of more effective urban planning for the future.

\section{Introduction}

According to Dufek (2008), over the past century, few studies have been published and are available in international level on extreme rainfall events and temperature alterations whether in global, hemispheric, and particularly regional scales (Acquaotta et al. 2014; Fratianni et al. 2014, 2009; Terzago et al. 2012). However, in recent decades, this situation has experienced strong changes due to the intense concern of scientists with the possibility of an eventual global climate change (Groisman 1999; IPCC 2013, 2007, 2001, 1992, 1990; Marengo 2008) and the damage that this could result in different parts of the planet.

Among the many effects that climate variability could be responsible for, a major concern is the imminence of a possible increase in the occurrence of extreme events around the globe, which could directly affect the human population and other living organisms. Several studies and investigations have been conducted in order to identify which elements of weather might be responsible for major natural and social impacts, besides understanding how these elements are causing such impacts and what are their intensities and frequencies of occurrences. As an example, we can cite the works of Easterling et al. (2000); Kalkstein (1993); Kunkel (1999); Meehl et al. (2000); and Walther et al. (2002), among many others.

Currently, climate scientists have dedicated great attention to the extreme variations of values of two main climate elements, the temperature and the precipitation. Among several previous studies, many have proven, for several regions around the world, real alterations in the values of these 
elements, as verified in the researches of Acquaotta and Fratianni (2013), Aguilar et al. (2005), Alexander et al. (2009, 2006), Besselaar et al. (2012), Klein Tank et al. (2006, 2003, 2002); Moberg et al. (2006); Mueller and Seneviratne (2012); Sen Roy and Rouault (2013); Terzago et al. (2013, 2010), Vincent et al. (2005), Vincent and Mekis (2006), and Wang et al. (2013).

Even with all these efforts, we must recognize that in some areas of the planet, few studies addressing changes in extremes of temperature and rainfall are available, especially when the scale of analysis is regional. Marengo et al. (2009) e.g., commented that among the main difficulties for those willing to perform a more detailed analysis in this sense. In Brazil or in other countries of South America, the major difficulties are related to the absence of long-term stations and also to the poor quality of series of data. Problems of poor spatial distribution of stations for data collection, short historical series or low quality of climate data are quite common characteristics in emerging countries, which are still in development processes, like Brazil. In the Brazilian case, it is also necessary to consider that, due to its territorial dimension, the several urban lacks and the long existent distances between municipalities in some regions of the country, make more difficult the implementation, control, and management of climate station of data collection (Acquaotta and Fratianni 2014).

Given all the problems exposed above, we consider that the production of research that is able to contribute to the understanding of possible changes that are occurring in the dynamic climate of Brazil, especially the precipitation, can be extremely positive in the sense of adding the results obtained in this region with those of many other regions that have been studied around the world. Furthermore, this kind of research supports the achievement of better planning for this country in order to minimize adverse impacts and consequences that alteration in extreme values of precipitation can result to the society, e.g., flood events, inundation, landslide slopes in urban areas, and damage in agriculture, generating impacts on food production. All these problems are common in Brazil, a country where the climate is predominantly tropical, but with strong subtropical influences, contributing to very contrasting climate changes, even in normal conditions.

Thus, aiming at contributing to a better understanding of pluviometric alterations that have been recorded in Brazil, in the present research, efforts were concentrated on the interpretation of the rainfall in the catchment area of the Paraná River Hydrographical Basin, an extensive region of Brazil, which is considered the most important socioeconomic region of the great Brazilian hydrographic regions, since it presents the highest population density in this country ( $32 \%$ of the population), mainly concentrated in large and important municipalities (ANA 2013). The Paraná River Basin also presents the largest Brazilian hydroelectric park (176 hydroelectric power plant) and the greater capacity for energy production in the country ( $59.3 \%$ of the total national). Due to the high rate of industrialization, the basin has the highest energy demand of the country, consuming nearly $75 \%$ of the national expenditure (ANEEL 2013a). This basin is, obviously, extremely dependent on rainfall catchment, and any change in the dynamic of this climatic element can induce major impacts to the population, in several socioeconomic sectors.

Therefore, the main aim of this research is to present the changes that have been occurring in the pluviometric dynamics of the Paraná River Hydrographical Basin in the Brazilian portion, in order to contribute to a better socioeconomic planning of the area. This way, we expect to collaborate with the results obtained in previous investigations, some of them covering the entire area of the basin (Boulanger et al. 2005; Camilloni and Barros 2003; Krepper and Zucarelli 2010; Penalba and Robledo 2010; Silva and Berbery 2006; Zandonadi 2009), some covering smaller areas within its territory (Boin 2000; Dufek and Ambrizzi 2008; Monteiro 1973, 2000; Zavattini 1990), and even some studies covering the neighboring or continuing areas of its territorial boundaries (Barros et al. 2008; Figueiró and Coelho Netto 2011; Grimm et al. 2000; Groisman et al. 2005; Haylock et al. 2006; Liebmann et al. 2004). This research also aims at supporting future researches by utilizing the rain as the main guiding element of its discussions, especially for tropical and equatorial climates, where rainfall influence is always very intense.

\section{The Paraná River Hydrographic Basin}

The Paraná River Hydrographic Basin is located in Brazil, between the geographical coordinates of $15^{\circ} 25^{\prime} 47^{\prime \prime}$ and $26^{\circ}$ $50^{\prime} 55^{\prime \prime}$ South latitude and $43^{\circ} 34^{\prime} 55^{\prime \prime}$ and $55^{\circ} 55^{\prime} 53^{\prime \prime}$ West longitude (Fig. 1). It is the second largest Brazilian river basin, and its area $\left(879,860 \mathrm{Km}^{2}\right)$ occupies $10 \%$ of the national territory, distributed among the states of São Paulo, Paraná, Mato Grosso do Sul, Minas Gerais, Goiás, Santa Catarina, and the Federal District. It borders five other major Brazilian hydrographic regions: the North, with the Tocantins-Araguaia Basin; the Northwest, with the Paraguay Basin; the Northeast, with the São Francisco River Basin, the Southeast, with the Eastern Atlantic; and the South, with the Uruguay Basin (ANEEL 2013b e ANA 2013).

The Paraná River Hydrographic Basin landscape is very irregular in the East and Southeast region, due to the occurrence of crystalline rocks and higher altitudes. In the other areas dominate tabular wavy shapes, with gentle slope toward the Paraná River, locally interrupted by cliffs of "Cuestas" of Serra Geral. The Central Plateau of the basin is characterized by elongated or tabular hills with bulging tops, arranged on three levels with altitudes near to $1000 \mathrm{~m}$, between $600 \mathrm{~m}$ and $700 \mathrm{~m}$, and to $500 \mathrm{~m}$. Since these levels are tilted, the altitudes decrease as approaching the main gutter. The highest level is 


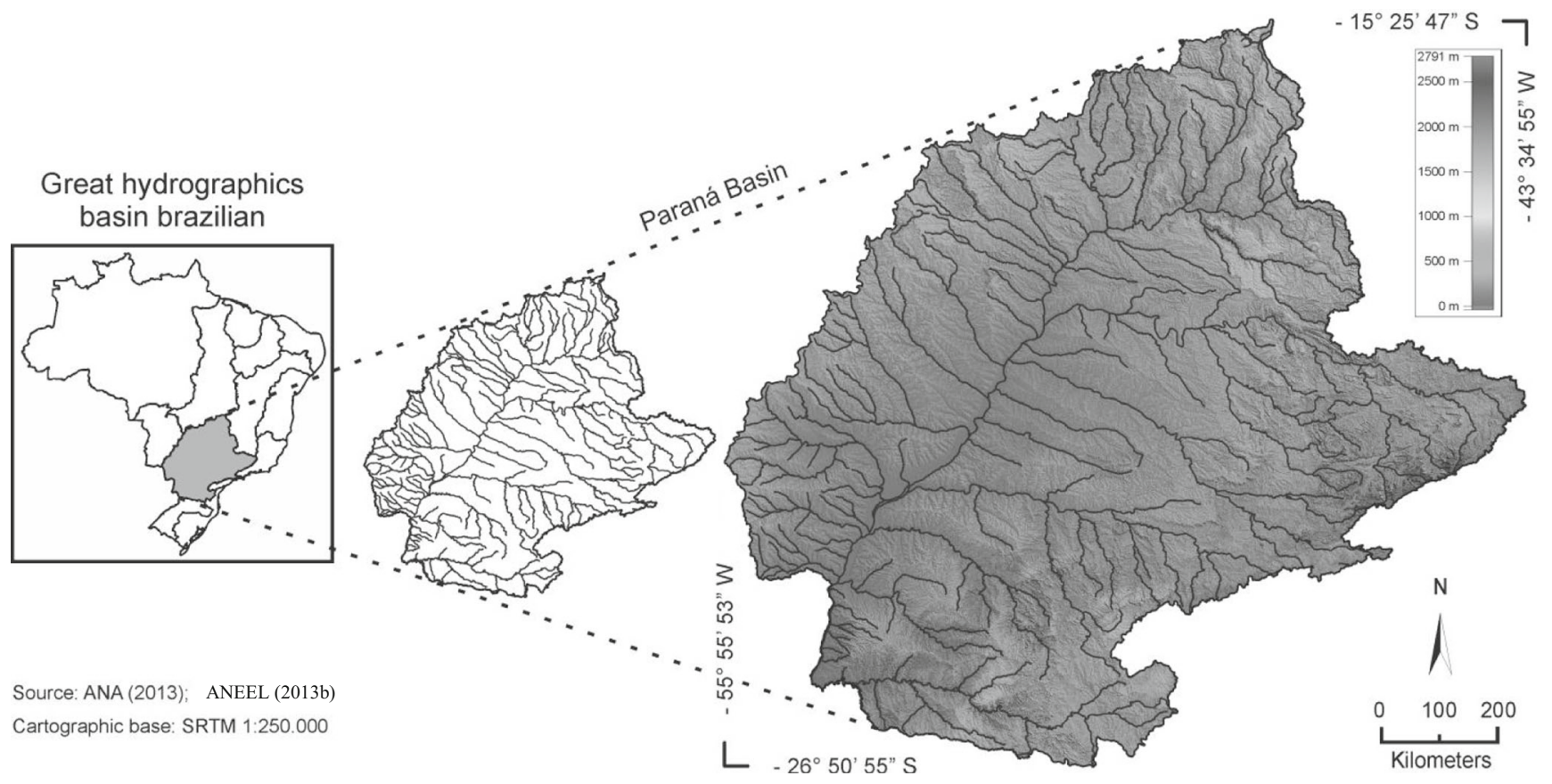

Fig. 1 Division of the major hydrographical regions of Brazilian territory, highlighting the Paraná River Hydrographic Basin, its main drainage system, and elevations of the landscape

referred as "Residual Plateaus Cuestiformes" and the others as "Reduced Plateaus" (Souza Filho and Stevaux 1997).

\section{Data and quality control}

Daily pluviometric data used in this research, for observation and analyses, were obtained initially from 44 meteorological stations, belonging to the National Institute of Meteorology (INMET 2013, 2009), a Brazilian government agency. The stations were distributed throughout the Paraná River Basin and covered the historical period from 1961 to 2011, 51 years.

The first process of analysis and quality control of the data was the verification of possible gaps in daily rainfall series from those initial 44 stations. To estimate the gap, we calculated the monthly and annual series. We created the monthly values only if at least $80 \%$ of the daily data was available, equal to a gap of 6 non-consecutive days (Klein Tank et al. 2002; Sneyers 1990) and for the annual values, at least the $96 \%$ of the daily data, equal to a gap of 15 non-consecutive days (Acquaotta et al. 2009; Klein Tank and Können 2003; Venema et al. 2012).

We observed that some of them contained a lot of missing data, in some cases, annual gaps, mainly during the years of 1979 to 1985 , which made impossible, for this period, any kind of verification of the results. In attempt of solving this problem, we have developed the historical research in the INMET Institute, responsible for the data who claimed to have been failures at the time of migration of data contained in a database of information given by an old computer system to another more modern. They affirmed that the problem is being solved. However, there is no definite date for the completion of the restoration project data.

This result precludes the use of the long series from 1961 to 2011. So, we have selected a new time period, from 1986 to 2011. However, the choice of this new period precludes, even more, the use of the pluviometric stations from western sector of the basin, a region that already had shortage of data, especially for being recently more economically developed, with few urban areas, and consequently, lower population densities, which contribute to the lower density of stations of data collection, as well as for the existence of shorter historical series, often with lower quality than in other regions of the basin.

Therefore, in addition to force the use of a shorter historical series, the poor quality of the data also led to a decrease in the number of stations of data collection to be used in the analysis, from a total of 44 to only 32 stations, which have their information presented in detail in Table 1. The location of these stations throughout the basin can be verified in Fig. 2, where it is also possible to observe the absence of stations in the extreme east and the southern regions, since in these regions, it was not possible to select stations with good quality of data which allow the application of the parameters and the verification of possible variations in pluviometric values during the select period.

To improve the dataset, we also used data from several stations outside the limits of the basin, to the high quality of data, and also to their vicinity to the basin, which ensure a better spatial coverage and higher quality of the investigated information. 
Table 1 List of the 32 pluviometric stations used in the analysis

\begin{tabular}{|c|c|c|c|c|c|}
\hline \multicolumn{2}{|c|}{ Pluviometric station } & \multirow{2}{*}{$\begin{array}{l}\text { Code (WMO) } \\
83579\end{array}$} & \multirow{2}{*}{$\begin{array}{l}\text { Latitude (S) } \\
-19.60\end{array}$} & \multirow{2}{*}{$\begin{array}{l}\text { Longitude (W) } \\
-46.93\end{array}$} & \multirow{2}{*}{$\begin{array}{l}\text { Elevation }(\mathrm{m}) \\
1023.6\end{array}$} \\
\hline 1 & Araxá & & & & \\
\hline 2 & Avaré & 83773 & -23.08 & -48.92 & 813.0 \\
\hline 3 & Brasília & 83377 & -15.79 & -47.92 & 1159.5 \\
\hline 4 & Campo Mourão & 83783 & -24.05 & -52.36 & 616.4 \\
\hline 5 & Campos do Jordão & 83714 & -22.73 & -45.58 & 1642.0 \\
\hline 6 & Capinópolis & 83514 & -18.68 & -49.56 & 620.6 \\
\hline 7 & Castro & 83813 & -24.78 & -50.00 & 1008.8 \\
\hline 8 & Catalão & 83526 & -18.17 & -47.95 & 840.5 \\
\hline 9 & Catanduva & 83676 & -21.13 & -48.96 & 570.0 \\
\hline 10 & Curitiba & 83842 & -25.30 & -49.20 & 923.5 \\
\hline 11 & Formosa & 83379 & -15.55 & -47.34 & 935.2 \\
\hline 12 & Franca & 83630 & -20.55 & -47.43 & 1026.2 \\
\hline 13 & Goiânia & 83423 & -16.67 & -49.26 & 741.5 \\
\hline 14 & Guarulhos & 83075 & -23.43 & -46.46 & 735.0 \\
\hline 15 & Ipamerí & 83522 & -17.72 & -48.17 & 773.0 \\
\hline 16 & Iratí & 83836 & -25.47 & -50.63 & 837.0 \\
\hline 17 & Ituiutaba & 83521 & -18.97 & -49.35 & 560.0 \\
\hline 18 & Jataí & 83464 & -17.93 & -51.72 & 662.9 \\
\hline 19 & Juiz de Fora & 83692 & -21.77 & -43.32 & 940.0 \\
\hline 20 & Lavras & 83687 & -21.23 & -45.00 & 918.8 \\
\hline 21 & Londrina & 83766 & -23.32 & -51.15 & 566.0 \\
\hline 22 & Maringá & 83767 & -23.42 & -51.95 & 542.0 \\
\hline 23 & Paracatú & 83479 & -17.22 & -46.87 & 712.0 \\
\hline 24 & Pirenópolis & 83376 & -15.85 & -48.96 & 740.0 \\
\hline 25 & Presidente Prudente & 83716 & -22.12 & -51.38 & 435.6 \\
\hline 26 & São Carlos & 83726 & -22.02 & -47.90 & 856.0 \\
\hline 27 & São Lourenço & 83736 & -22.10 & -45.02 & 953.2 \\
\hline 28 & São Paulo (Mirante de Santana) & 83781 & -23.50 & -46.62 & 792.1 \\
\hline 29 & São Simão & 83669 & -21.48 & -47.55 & 617.4 \\
\hline 30 & Uberaba & 83577 & -19.77 & -47.93 & 737.0 \\
\hline 31 & Unaí & 83428 & -16.37 & -46.88 & 460.0 \\
\hline 32 & Votuporanga & 83623 & -20.42 & -49.98 & 502.5 \\
\hline
\end{tabular}

Completing the process of choice of stations and periods to be utilized, on daily data, an accurate quality control was made by the software RClimdex (Zhang et al. 2004). The program highlights obviously wrong precipitation data, such as negative values, and creates plots that allow to visualize the behavior of the daily series (Fig. 3). Also the program highlights the outliers. The outliers are daily values outside a threshold; in this study, the threshold is the 99th percentile calculated for each series on the available period. The identification of the outliers, maximum values of daily precipitation, is very important, because it allows us to identify incorrect values due to erroneous transcription of the daily data. A typical example of a transcription error is a weekly accumulation that was transcribed as the value of one day. The incorrect values and outliers are transcribed and stored in tables by the software RClimdex to be analyzed and corrected later if necessary. Besides the program consider only the rainfall data equal or superior to $1 \mathrm{~mm}$, being discarded the data lower than $1 \mathrm{~mm}$, considering that such amount of rain are inexpressive to the analyses, not affecting consistently the rainfall in the basin Fig. 4.

\section{Climate indices}

On the selected stations were calculated the climate indices in order to check the pluviometric behavior of the study area. In total, there are 11 indices created and organized by the ETCCDI to perform the calculations applied to the studies on rainfall data (Table 2).

The joint CCl/CLIVAR/JCOMM Expert Team (ET) on Climate Change Detection and Indices (ETCCDI) has addressed the need for the objective measurement and characterization of 
Fig. 2 Location of the 32 pluviometric stations used in the analysis

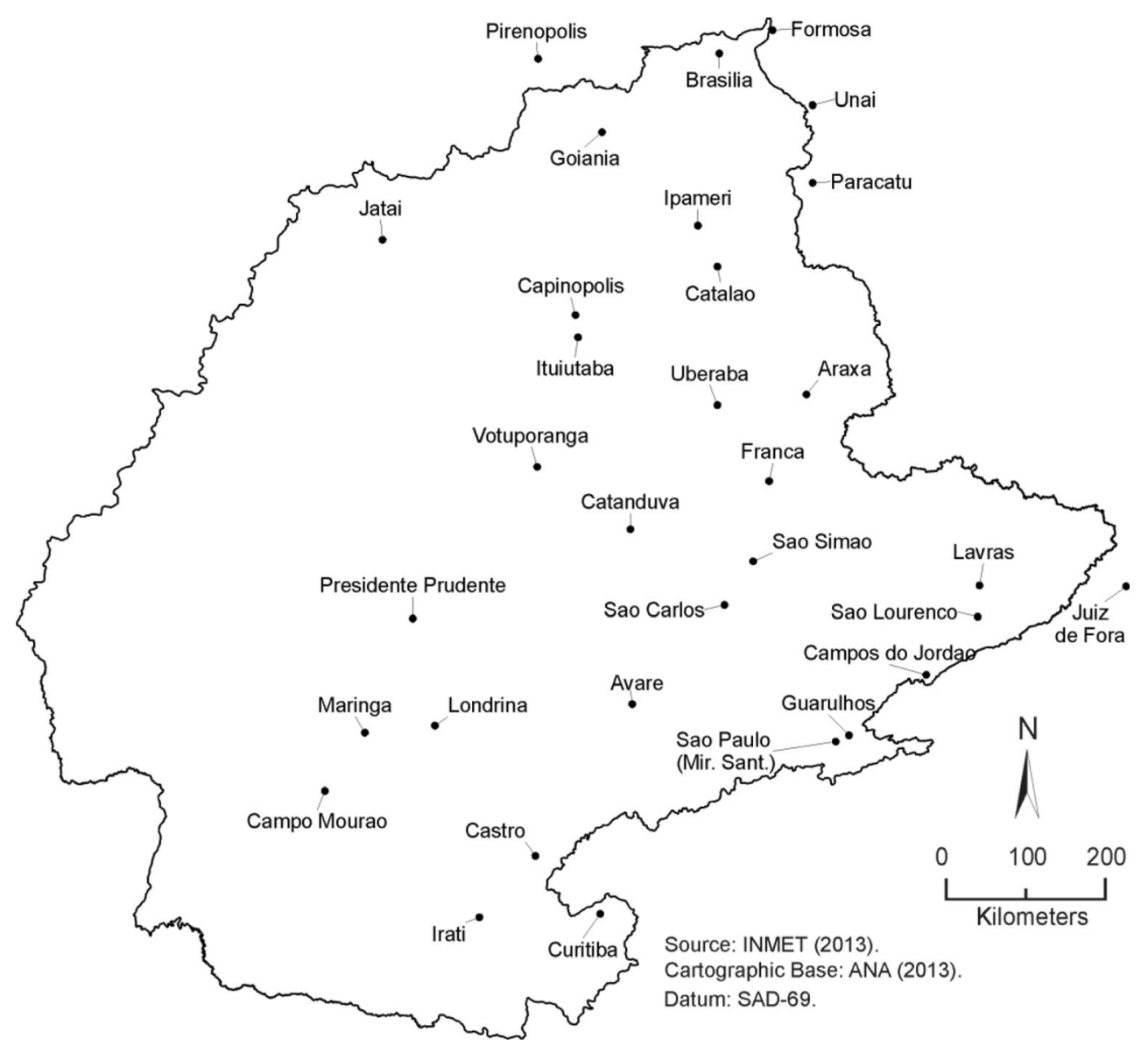

climate variability and change by providing international coordination and helping organizing collaboration on climate change detection and indices relevant to climate change revealing. The Expert Team (ET) and its predecessor, the CCl/CLIVAR Working Group (WG) on Climate Change Detection, have been coordinating an international effort to develop, calculate, and analyze a suite of indices so that individuals, countries, and regions can calculate the indices in exactly the same way such that their analyses will fit seamlessly into the global picture (Karl et al. 1999; Peterson et al. 2001).

The 11 indices were calculated on an annual scale. Reported in Table 2 are the definitions of the indices. For the monthly indices, RX1day and RX5day, the annual values were calculated as the maximum values of the monthly data.

The percentile indices, R95p and R99p, use threshold closely linked with the peculiarity of the station. The percentile is calculated on the reference period in our case in the analyzed time period, from 1986-2011. The methodology uses bootstrapping for calculating the base period values, so there is no discontinuity in the indices time series at the beginning or end of the base period (Zhang et al. 2005). In this way, it is possible to calculate for each of the stations the heavy precipitation. The threshold of extreme events can change considerably in a large area as the analyzed zone. Instead, some indices, R10mm and $\mathrm{R} 20 \mathrm{~mm}$, use a determinate threshold to highlight as the same events change from station to station.

For each pluviometric index, the trends were also calculated, by linear least square. The Mann-Kendall test for the trend is then run on the time series to compute the level of significance, $95 \%$ level. To evaluate the serial correlation of the data, the series has been analyzed with the Wald-Wolfowitz test (Sneyers 1990; Yue et al. 2002).
Fig. 3 Example of plot showing the periods with gaps in the data generated by RClimdex software

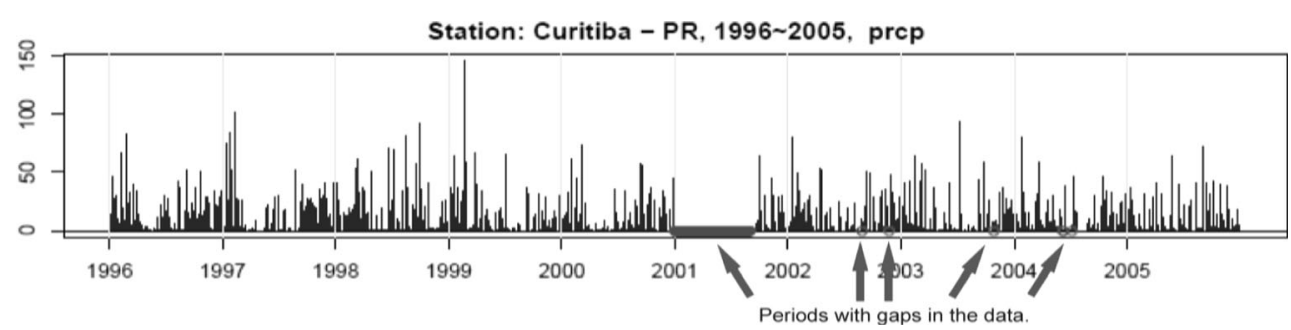


Fig. 4 Climate classification of Brazil according to the actions and influences of masses of air, highlighting the Paraná River Hydrographic Basin Organized by Zandonadi (2013)

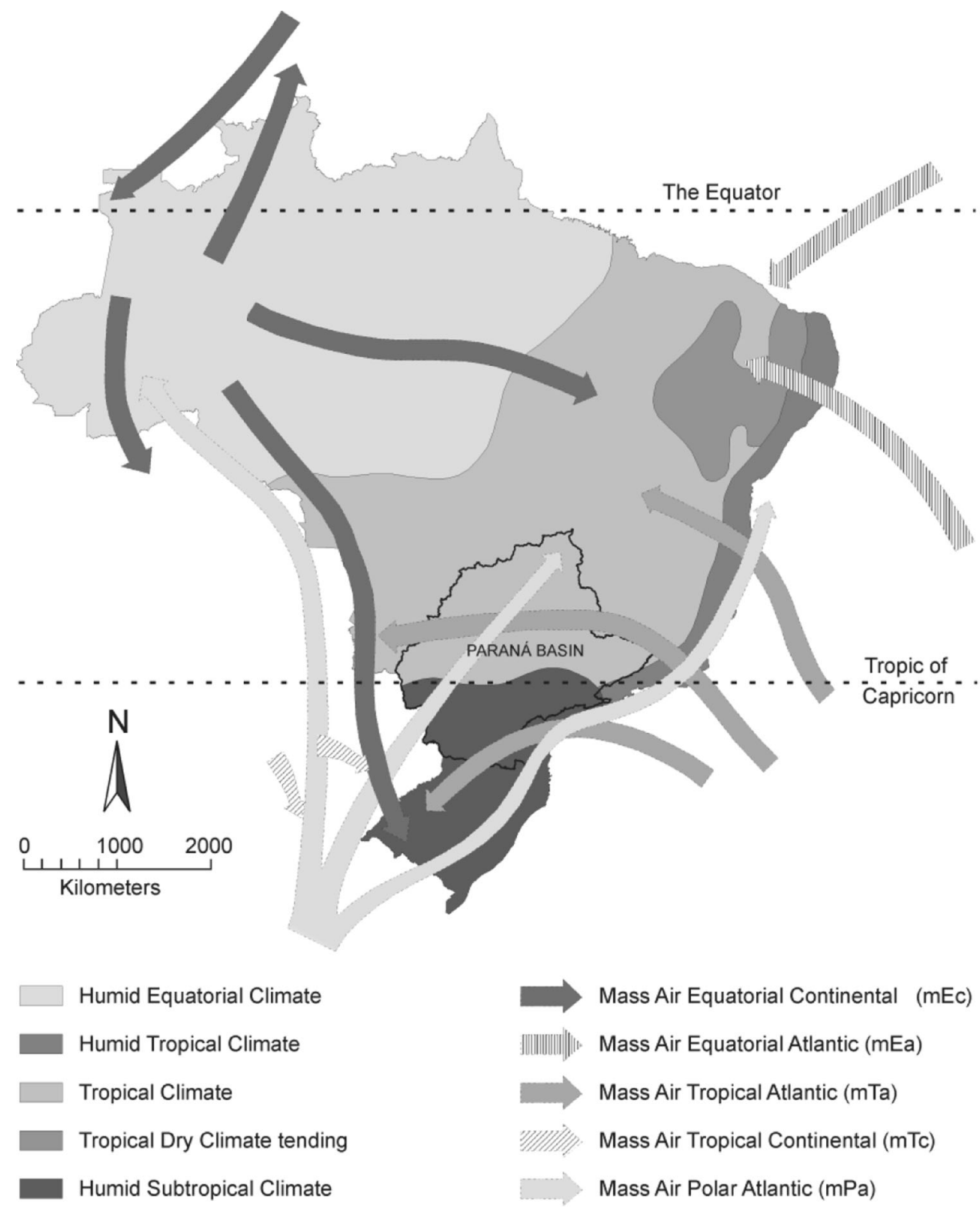

Adapted from: Strahler (1951) _ Monteiro (1962; 1963a; 1963b; 1964) and Mendonça \& Danni-Oliveira (2007). Organized by: Zandonadi, L. (2013).

All positive and negative values, respectively, indicative of the increase or decrease of the trend, were organized in a spreadsheet in order to facilitate observation and analysis, allowing to verify which areas had the most significant pluviometric alteration. All values of negative and positive trends for each of the 11 indices were divided in 7 ranges of classes. Thus, the first range is from 0 to 3 , the second from 3 to 6 , the third from 6 to 9 , the fourth from 9 to 12 , the fifth from 12 to 15 , the sixth from 15 to 18 , and the seventh from 18 to 21 .

Finally, we have chosen two large urban areas located within the basin, the municipalities of Curitiba and Goiânia, both representing two different climatic regions present in the study area (Fig. 2). The aim of this step was to identify which amount of rainfall can eventually cause impacts in these two urban centers, such as floods and inundations. The study of the variations of precipitation by using climate indices allows us to understand if the risks of occurrences of new impacts will increase or not. Then we have selected these centers because it is possible to consult a great number of works regarding these issues.

\section{Climatic aspects of Brazil and Paraná River Hydrographic Basin}

Due to its continental dimensions, Brazil has a very broad climate diversification, influenced by its geographic location, its 
Table 2 Identification and definitions of rainfall indices used in the research

\begin{tabular}{|c|c|c|c|}
\hline ID & Indicator name & Definitions & Units \\
\hline RX1day & Maximum 1-day precipitation amount & Monthly maximum 1-day precipitation & $\mathrm{mm}$ \\
\hline RX5day & Maximum 5-day precipitation amount & Monthly maximum consecutive 5-day precipitation & $\mathrm{mm}$ \\
\hline SDII & Simple daily intensity index & $\begin{array}{l}\text { Annual total precipitation divided by the number of wet } \\
\text { days (defined as precipitation }>=1.0 \mathrm{~mm} \text { ) in the year }\end{array}$ & $\mathrm{mm} /$ day \\
\hline $\mathrm{R} 10 \mathrm{~mm}$ & Number of heavy precipitation days & Annual count of days when precipitation $>=10 \mathrm{~mm}$ & days \\
\hline $\mathrm{R} 20 \mathrm{~mm}$ & Number of very heavy precipitation days & Annual count of days when precipitation $>=20 \mathrm{~mm}$ & days \\
\hline $\mathrm{R} 1 \mathrm{~mm}$ & Number of rainy days & Annual count of days when precipitation $>=1.0 \mathrm{~mm}$ & days \\
\hline CDD & Consecutive dry days & Maximum number of consecutive days with daily rainfall $<1 \mathrm{~mm}$ & days \\
\hline CWD & Consecutive wet days & Maximum number of consecutive days with daily rainfall $>=1 \mathrm{~mm}$ & days \\
\hline R95p & Heavy precipitation & Annual total precipitation from daily rainfall $>95$ th percentile & $\mathrm{mm}$ \\
\hline R99p & Extreme precipitation & Annual total precipitation from daily rainfall $>99$ th percentile & $\mathrm{mm}$ \\
\hline PRCPTOT & Annual total wet-day precipitation & Annual total precipitation in wet days (daily rainfall $>=1 \mathrm{~mm}$ ) & $\mathrm{mm}$ \\
\hline
\end{tabular}

significant coastal extension, its importance, and the different air masses that act on its territory. Among all these facts, the masses of air play an important role in the climate configuration, by having high mobility and dynamism, being generators of atmospheric currents that control all the acting general circulation in the Brazilian geographical space. Along the many paths that air masses ranging in the Brazilian territory, there are always interactions with multiple geographic features, such as the landscape, which always end up causing temperature variations and very contrasting rain throughout the country. Added to all this complex interaction, we must also consider the influences caused by other systems and atmospheric phenomena, as in the case of the South Atlantic Convergence Zone (SACZ) and the El Niño and La Niña, the last two difficult to predict.

Monteiro $(2000,1973)$ performed a clear demonstration of the action of these air masses, proposing a regional climate classification, based on the atmospheric dynamics acting in São Paulo State, in Brazil, using rain and landscape as guiding elements of his suggestion for classification of active weather in the region. In his proposal, Monteiro, besides confirming the existence of climate division demonstrated by Strahler (1951) to the region, also admitted that the division between those two major climatic groups occurs through a range of mobile transition. Such mobility is caused by the time of active masses of air in that region and spatial dynamics, and depends on the intensity of the centers of action that originate such masses, as well as, on how often they act in the region.

Still utilizing the element rain to perform a proposal for climate classification of genetic basis, at regional level, Zavatini (1990) and Zavattini (2009) also identified the continuation of this same line of transition between the two major climates, this time studying the Mato Grosso do Sul State.

The unification of these three climatic classification, which have the verification of the genesis of rain as the basis of their analyses, by means of identification of atmospheric systems who originated them, was presented recently by Zavattini and Boin (2013), providing further clarification on climate setting existing within the Paraná River Hydrographical Basin. The presence of a climatic zone transition over the basin causes great pluviometric instability, which, when associated with a variation of landscape, generates greater volumes of rain in some areas and disabilities in others. This is one of the reasons because the whole central part of the basin is less watered by rainfall, since the area of higher atmospheric instability, caused by the climate transition line that separates the various active weather systems, is coincident with the area where the landscape is more flattened and present lower altitudes, generating lower interactions climate-landscape and, consequently, a decrease in orographic rainfall.

This pluviometric behavior had been verified by Zandonadi (2009) on research conducted to identify the distribution of rainfall in the Paraná River Hydrographical Basin. When using as a parameter of analysis the total annual rainfall for the period from 1976 to 2005 (Fig. 5), the author concluded that the accumulated rainfall occurred exactly in the lower central region of the basin, especially near the Paraná riverbed, for both, years of habitual pattern (years that most recur throughout the analyzed series), and years considered extreme, in moments that the amount of rainfall was very high or far below what is considered normal. Another rainfall pattern observed in this study was that the highest quantity of annual rainfall is concentrated in the of the basin, due to higher influence of masses of air and polar fronts, arriving in this region more frequently than in other regions, causing a more homogeneous annual rainfall distribution. Also, when entering the basin, these masses of air and polar fronts interact with the higher altitudes of the southern landscape center, causing orographic rainfall, or, often holding the atmospheric systems for some more days, contributing to the increase in the amount of precipitation.

The biggest influence of the landscape on the rainfall quantity was noticed by Zandonadi (2009) at the extreme eastern, in the Serra da Mantiqueira, with the higher altitudes of the basin, 


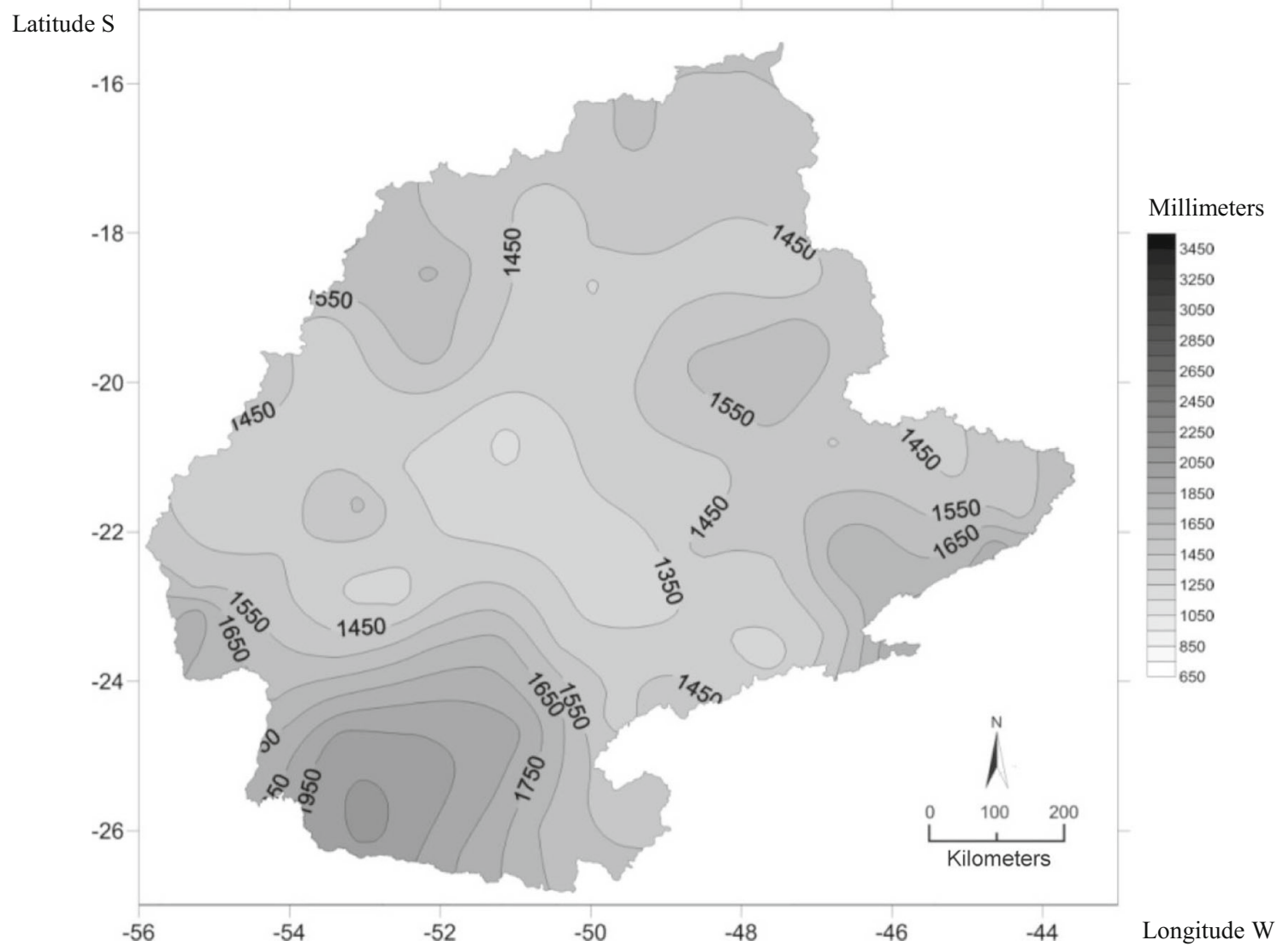

Fig. 5 Mean annual rainfall distribution in the Paraná River Hydrographic Basin, in the period from 1976 to 2005

approaching $3000 \mathrm{~m}$ of altitude. The Atlantic Tropical Mass may also influence the highest annual precipitation, verified in the extreme north and northeast of the studied area, however, with less influence than in the extreme east, since in this region the landscape is not as sharp as in that one.

Finally, the entire rainfall configuration shown above still has a very close proximity to the one shown by the INMET (2009), by means of the production of Brazilian Climatological Norms for the period from 1961 to 1990, demonstrating that the lowest annual rainfall average values occur exactly in the central part of the basin, increasing toward the higher areas, on their edges, and especially toward the south, where there are the highest annual average amounts.

\section{Results}

\subsection{Climate indices}

Observing Table 3, it is possible to consider that there is an increase in the heavy precipitation in most part of the Paraná River Hydrographic Basin. This increase is indicated by R95p (heavy precipitation index), SDII (simple daily intensity index), R20mm (number of very heavy precipitation days), and
R10mm (number of heavy precipitation days) that show positive trends in the most of stations. Averagely in 24 stations on 32 the trends are positive but not statistically significant in the most of cases. From the index R99p (extreme precipitation), the number of stations with increasing trends tends to reduce. The increase in intense rainfall directly reflects in the increase of the total annual rainfall, as shown in the PRCPTOT (annual total wet day precipitation index), where the majority of the stations ( 23 with positive trends) presented an increase in total annual precipitation amount. In some cases, the increase in the PRCPTOT index was significant, as observed in the stations Campos do Jordão and Juiz de Fora, who presented positive trends of $19.1 \mathrm{~mm} /$ year and $19.8 \mathrm{~mm} /$ year, respectively.

The indices R1mm (number of rainy days), CDD (consecutive dry days), CWD (consecutive wet days), R1Xday (max 1-day precipitation amount), and R5Xday (max 5-day precipitation amount) do not show a unique behavior. The number of stations with negative and positive trends is practically equivalent, and only for CWD index in Votuporanga, the trend is statistically significant, 0.15 days/year.

The results described above confirmed the actual alterations in rainfall for various stations. However, these analyses did not enable us to know exactly what are the areas of the basin in which these changes are occurring, and, in order to support this understanding, maps representing the spatial 
Table 3 Positive (light gray cells) and negative (dark gray cells) trends for each verified index in the 32 stations, from 1986 to 2011

\begin{tabular}{|c|c|c|c|c|c|c|c|c|c|c|c|}
\hline Pluviometric Station & CDD & CWD & RX1day & RX5day & SDII & R1mm & R10mm & $\mathbf{R 2 0} \mathbf{m m}$ & R95p & R99p & PRCPTOT \\
\hline Araxá & -0.6 & 0.1 & 0.2 & 0.1 & 0.1 & 0.0 & 0.1 & 0.2 & 8.5 & 2.2 & 8.9 \\
\hline Avaré & -0.1 & -0.1 & -0.1 & -0.7 & 0.0 & -0.3 & 0.0 & 0.0 & -1.7 & 3.8 & -2.0 \\
\hline Brasília & 1.1 & 0.1 & 0.2 & 1.7 & 0.0 & 0.0 & 0.0 & 0.1 & 3.4 & -0.7 & 1.6 \\
\hline Campo Mourão & -0.2 & -0.1 & -0.2 & -0.3 & 0.1 & -0.5 & 0.0 & 0.1 & -0.8 & -0.5 & -2.0 \\
\hline Campos do Jordão & 0.0 & 0.0 & 0.1 & 1.2 & 0.1 & 0.6 & 0.6 & 0.4 & 10.4 & 0.6 & 19.1 \\
\hline Capinópolis & 0.2 & 0.0 & -0.4 & 0.7 & 0.0 & -0.1 & 0.2 & 0.1 & 0.7 & 1.0 & 1.0 \\
\hline Castro & -0.1 & -0.1 & 1.1 & 0.2 & 0.1 & 0.3 & 0.3 & 0.3 & 1.6 & 0.8 & 10.3 \\
\hline Catalão & 0.7 & -0.1 & -0.3 & -0.7 & 0.1 & 0.1 & 0.3 & 0.2 & 2.8 & 1.3 & 6.8 \\
\hline Catanduva & 0.1 & 0.0 & -1.0 & -1.6 & 0.0 & -0.2 & -0.3 & -0.2 & 0.9 & -3.0 & -5.7 \\
\hline Curitiba & -0.2 & 0.0 & 0.7 & 0.3 & 0.1 & 0.2 & 0.4 & 0.2 & 7.3 & 2.0 & 12.0 \\
\hline Formosa & 0.9 & 0.0 & -0.2 & -0.3 & 0.0 & -0.1 & -0.3 & -0.1 & 1.5 & 0.2 & -3.5 \\
\hline Franca & -0.1 & -0.1 & -0.3 & -0.4 & 0.0 & 0.4 & 0.2 & 0.2 & 2.2 & -1.2 & 8.9 \\
\hline Goiânia & 0.6 & 0.0 & 0.9 & 0.6 & 0.1 & -0.2 & 0.1 & 0.0 & 3.0 & 4.4 & 5.4 \\
\hline Guarulhos & 0.2 & 0.0 & 0.0 & 0.0 & 0.0 & -0.2 & -0.2 & 0.0 & 3.7 & 2.3 & -1.2 \\
\hline Ipamerí & 0.6 & 0.1 & -0.1 & 0.0 & 0.0 & -0.1 & 0.1 & 0.2 & -1.5 & 0.1 & 1.1 \\
\hline Iratí & -0.2 & 0.0 & -1.1 & 0.5 & 0.0 & 0.2 & 0.1 & 0.2 & -0.3 & -0.1 & 4.7 \\
\hline Ituiutaba & -1.1 & 0.1 & -0.3 & -1.0 & 0.0 & 0.5 & 0.1 & 0.0 & 4.2 & -0.1 & 5.3 \\
\hline Jataí & 0.0 & -0.1 & 0.2 & 0.8 & 0.0 & -0.2 & -0.2 & -0.1 & 4.0 & 1.6 & -1.8 \\
\hline Juiz de Fora & 0.1 & 0.2 & 0.7 & 0.6 & 0.1 & 0.6 & 0.6 & 0.4 & 11.3 & 6.4 & 19.8 \\
\hline Lavras & -0.9 & 0.1 & -0.5 & -0.1 & 0.0 & -0.2 & -0.1 & 0.1 & 0.8 & -2.1 & 0.7 \\
\hline Londrina & -0.9 & 0.2 & 1.5 & 2.6 & 0.0 & 0.5 & 0.2 & 0.2 & 5.0 & 3.9 & 12.5 \\
\hline Maringá & -0.2 & -0.1 & 0.3 & 0.1 & 0.0 & -0.1 & 0.1 & 0.1 & -2.8 & 2.8 & 1.9 \\
\hline Paracatú & 1.4 & 0.1 & -0.4 & 0.6 & 0.1 & -0.1 & 0.1 & 0.2 & 5.2 & -0.7 & 5.2 \\
\hline Pirenópolis & 0.4 & -0.1 & -0.2 & -0.5 & 0.1 & -0.1 & 0.0 & 0.1 & 1.9 & -0.3 & 2.4 \\
\hline Presidente Prudente & 0.3 & -0.1 & -0.3 & 1.6 & 0.0 & 0.0 & 0.0 & 0.1 & 3.5 & -2.0 & 3.5 \\
\hline São Carlos & -0.2 & -0.1 & 0.1 & -1.5 & 0.0 & 0.0 & -0.1 & -0.1 & 2.8 & -0.1 & -1.3 \\
\hline São Lourenço & 0.4 & 0.0 & 0.4 & 1.8 & 0.0 & 0.0 & -0.1 & 0.1 & -0.4 & -1.3 & -0.8 \\
\hline São Paulo (Mirante de Santana) & 0.4 & 0.0 & 0.2 & -0.2 & 0.1 & -0.5 & -0.1 & 0.1 & 3.2 & -0.2 & 2.8 \\
\hline São Simão & -0.1 & 0.0 & 0.2 & 1.2 & 0.0 & -0.1 & -0.3 & 0.1 & 10.0 & 2.7 & 1.9 \\
\hline Uberaba & 0.1 & -0.1 & -0.5 & 0.1 & 0.1 & -0.1 & 0.2 & 0.3 & 3.7 & -0.8 & 9.2 \\
\hline Unaí & 0.6 & 0.0 & -0.1 & -1.9 & -0.1 & -0.4 & -0.1 & -0.1 & -8.6 & -2.1 & -11.3 \\
\hline Votuporanga & 0.6 & 0.2 & 0.8 & 2.6 & 0.0 & 0.2 & 0.0 & -0.1 & 9.2 & 3.4 & 5.6 \\
\hline
\end{tabular}

White cells indicate the indices that did not present alterations and the highlight values $($ bold $)$ represent the trends significant at $95 \%$ significant level

distribution of trend values were prepared. These maps are shown in Fig. 6.

It is important to highlight that, even after the production of maps, it was difficult to establish a spatial pattern for each rainfall, given the heterogeneity shown by the values of trends over the study area. However, one more time, it was possible to clearly recognize that there are alterations in the pluviometric behavior. On the map of the CDD index, for example, it is possible to see that the entire southern region of the basin showed declining trends of consecutive dry days, and this pattern is exactly the opposite of what occurs in the northern region of the basin, where trends indicate an increase in consecutive dry days. These patterns are somehow understandable, since the south of the basin is more influenced by the Pacific polar mass and by frontal systems, which, when invade the region with more intensity 

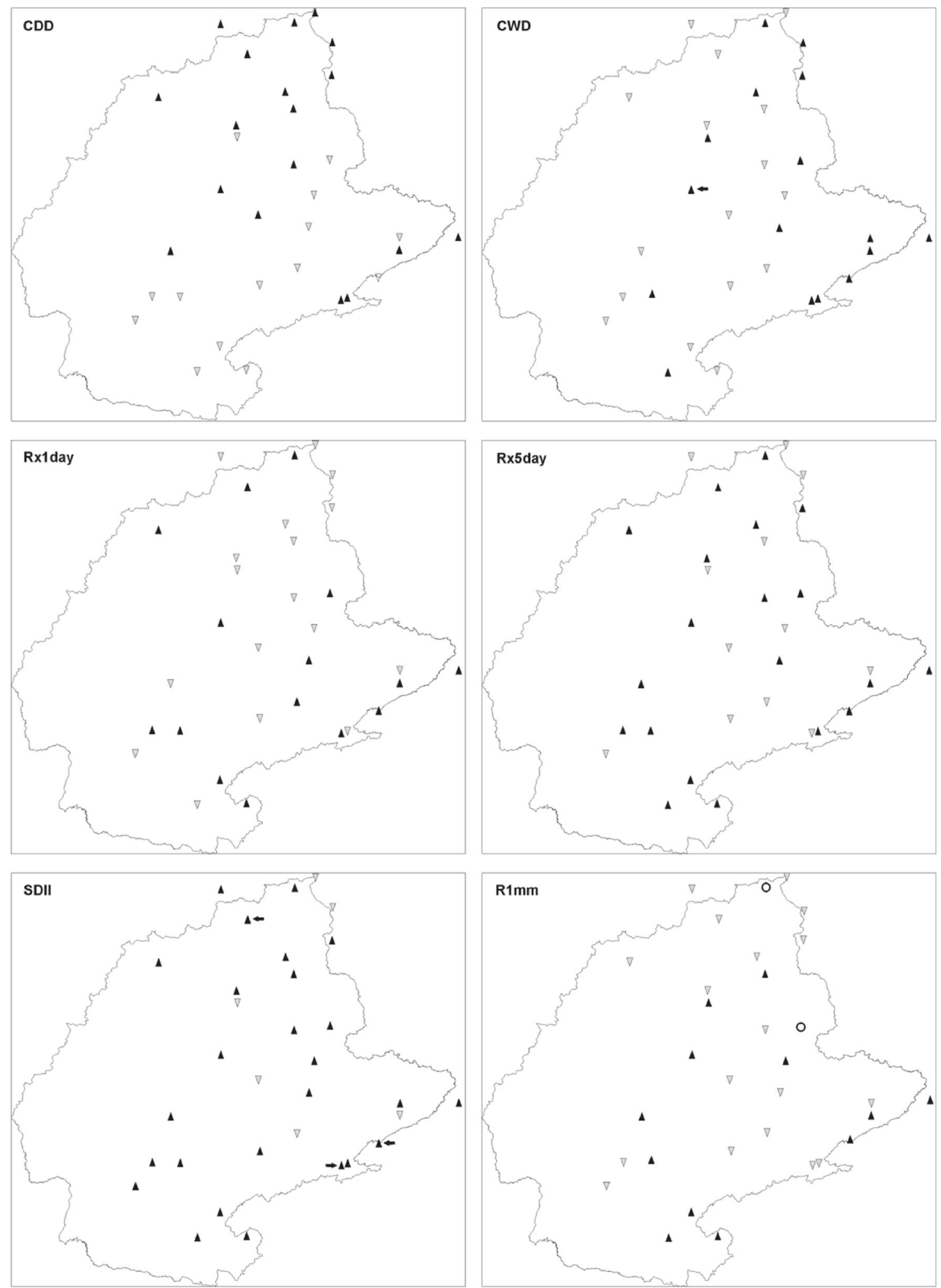

Fig. 6 Spatial distribution of positive (light gray triangles) and negative (dark gray triangles) trends of 11 climate indices, calculated for the 32 pluviometric stations in the period from 1986 to 2011. The

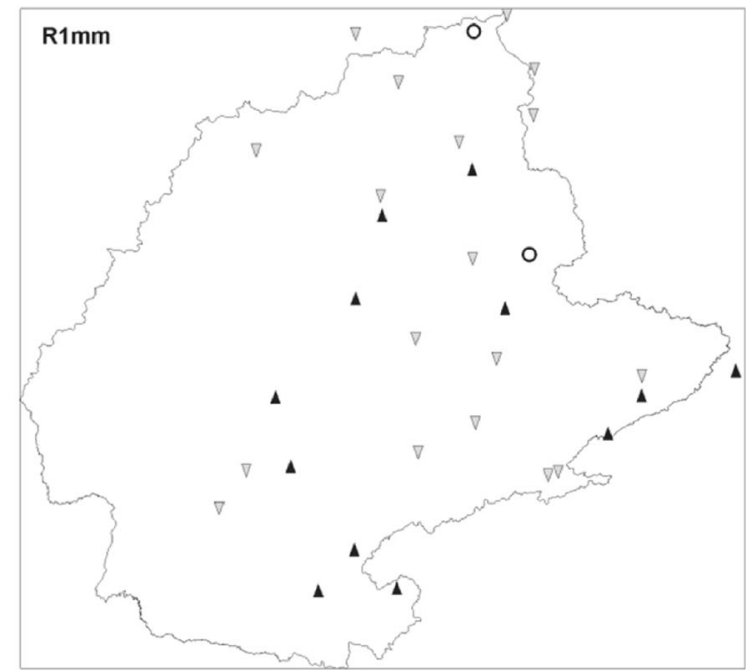

positive and negative. The white circles represent the indices that showed zero trends. The black arrows indicate the stations with trends significant at $95 \%$ significant level 

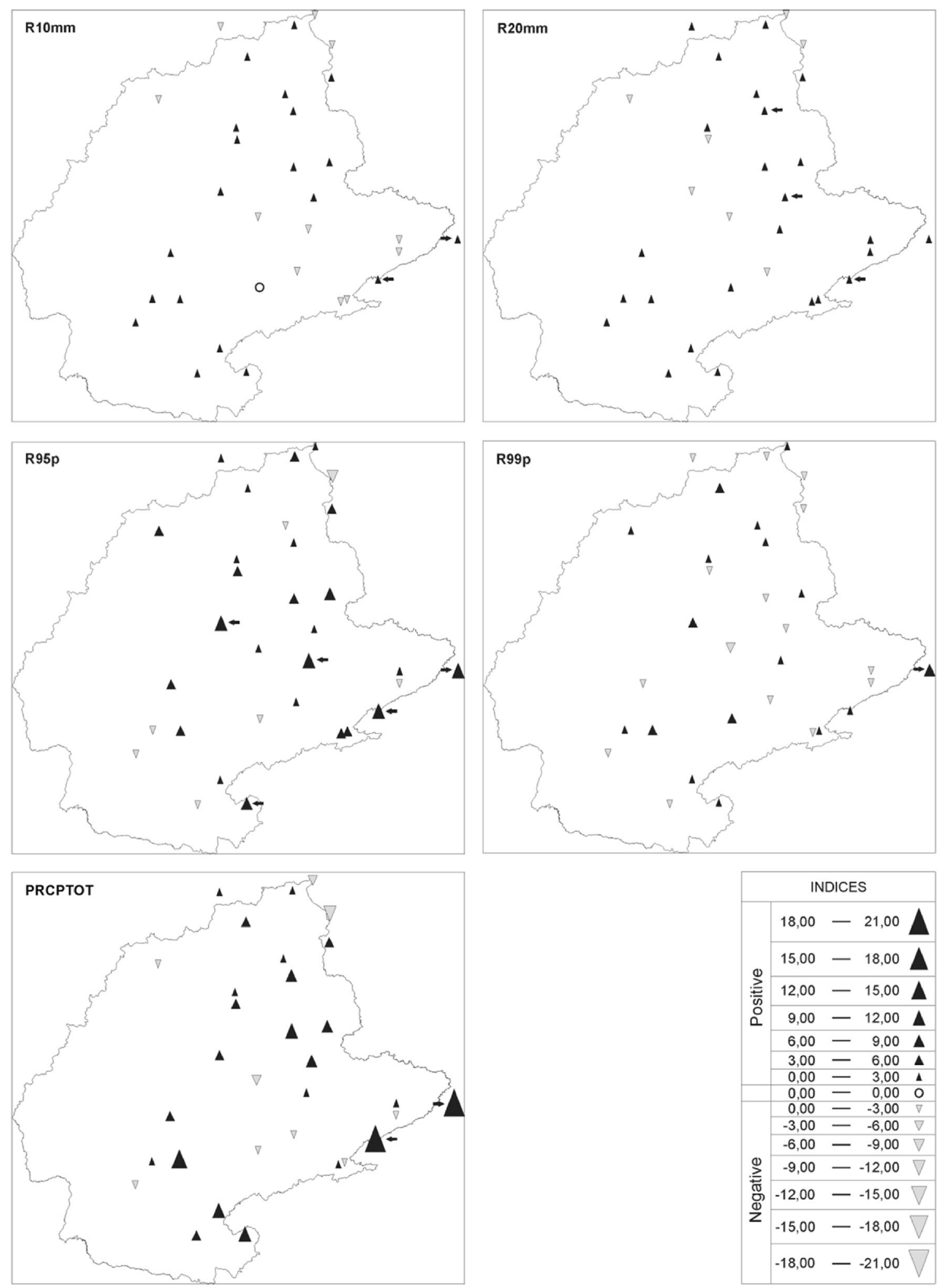

Fig. 6 (continued)

throughout the year, can be responsible for rains that are distributed more homogeneously temporally, reducing the chances of occurring prolonged dry periods. On the other hand, in the northern region, more influenced by topical and equatorial masses, rainfalls tend to be more massive, but of short duration, since they are primarily generated by the intense convection of air caused by higher temperatures throughout the year. 
For the CWD index, which represents the occurrence of consecutive wet days with rainfall higher than $1 \mathrm{~mm}$, the only spatial pattern is noticed in the eastern region of the basin, exactly where are the most complex topography and highest landscapes of the study area. The interaction with the landscape can also be essential for the occurrences of wet days, once this is a region that is often influenced by the Atlantic Tropical Mass, of oceanic origin, carrying a lot of moisture. Evidence of trends of decreased in occurrence of consecutive dry days (CDD) presented for the southern region, as well as increasing trends of consecutive wet days (CWD) into the eastern region, can be done through the interpretation of the RX5day index, of trend of occurrence of 5 consecutive days of rain, since it shows that the two regions had a decrease in the numbers of dry days and an increase of wet days. The SDII index that shows the intensity confirms this statement, which, incidentally, showed increases of the trends not only for the southern and eastern regions, but for almost the entire study area.

The calculated index used to show the values of trends for total annual precipitation (PRCPTOT) indicated that there was an increase in extreme rainfall for the eastern region. Comparing the trends shown by the PRCPTOT index with the R1mm, R10mm, R20mm, R95p, and R99p, it is clear that the increases in rainfall in the eastern region were mainly caused by the increase in extreme rainfall events, especially those above 95th percentile (95p). The rainfall above R99p had also great impact, but with less participation than the $95 \mathrm{p}$. Despite rainfall above 10 and $20 \mathrm{~mm}$ have increasing trends of less significant occurrence, they also contributed to the total annual rainfall to be higher in this region.

Contrary to what occurred in the eastern part of the basin, the significant increase in annual total wet-day precipitation (PRCPTOT) of the most part of the southern region is not that significant when compared with the increases in extreme rainfall (R95p and R99p), but with less intense precipitation, mainly over 10 and $20 \mathrm{~mm}$. Such behavior can be directly influenced by the greater temporal homogeneity of rainfall in this part of the basin, attributed to the actions of more constant polar mass and frontal systems.

The trends in significant increase in total annual rainfall in north-central sector of the basin are also related to higher rates of heavy rain, mainly above 95th percentile, as well as to the highest event of rainfall above $10 \mathrm{~mm}$. On the other hand, the northern extreme showed trends of rainfall declining, caused mainly by the reduction in the occurrences of less intense rainfall and, in some cases, in rainfall over 95th percentile.

\subsection{Heavy precipitation impact}

One of the major problems of large Brazilian towns are the damages caused by floods and inundations, which is directly related to the very intense rainfalls and can be responsible for diverse socioeconomic impacts. The prediction of when and with what amount these rains will happen is not easy, however, the knowledge of the pluviometric limits able to cause the greatest impacts may ensure that more effective actions and planning are implemented, minimizing the effects caused by extreme rainfall in the urban environment. To select these pluviometric thresholds from 1986 to 2011, we have classified by percentiles, the rains of two large Brazilian towns, the municipalities of Curitiba and Goiânia, both located in the Paraná River Hydrographic Basin, and each representing one distinct climatic region.

It was possible to study only these two locations because there are no many scientific literature on this analysis. Most of the analyzed series are unpublished. It is the first time that these were studied. Curitiba and Goiânia are the only two big towns with a good scientific research and situated in two different climate area where floods and inundations were studied in detail and the values of threshold that trigger these events were calculated.

The municipality of Curitiba is located in the southern of the basin, a region where the climate is mainly controlled by tropical and equatorial air masses. Therefore, once they are mainly associated with these systems, rainfalls are most often frontal, and depending on the atmospheric conditions and the interaction with the landscape that last for several days. Furthermore, the increased presence of these systems lead to a better distribution of the rain throughout the year.

Unlike Curitiba, the municipality of Goiânia, located in the northern part of the basin, a region where the climate is controlled by equatorial and tropical masses of air, and the distribution of rain is not as well spread throughout the year, since in this region, there is a period when rainfall is more intense (spring and summer) and, another is that, it is more scarce (autumn and winter). Moreover, in Goiânia, there are more torrential types of rainfall, which may present very expressive of rain, in short periods of time. This is a very common type of rain in some areas of the basin since the presence of higher temperatures, which causes the ascension of air and evaporation, is more intense, favoring the formation of large clouds heavily laden with moisture that are often associated to very intense storms.

According to research conducted by Cunico et al. (2002) and Zanella (2006), the most problematic cases related to floods and inundations in the municipality of Curitiba occurred due to daily amounts of rainfall that exceeded $60 \mathrm{~mm}$. However, both authors point out that there were already cases of impacts caused by lower volume of rainfall, especially when the sums of these smaller amounts occurred in daily sequences till reach $60 \mathrm{~mm}$. According to Hack (2002) amount of rainfall equal to or above $100 \mathrm{~mm}$, in $24 \mathrm{~h}$, assume a character of calamity in the municipality of Curitiba.

The threshold, $60 \mathrm{~mm}$, for the municipality of Curitiba corresponds to $98^{\text {th }}$ percentile of daily rainfall, calculated from 
1986 to 2011. This value is classified as extreme rain highlighted by R99p and observing its trend, $2.04 \mathrm{~mm} /$ year, it is evident as during the years the probability of floods increases. Furthermore, it was observed that the highest rainfall amount recorded in this town, for a single day, was $146.2 \mathrm{~mm}$, i.e., two times higher than the value recorded as responsible for impacts.

In the same period, the municipality of Goiânia presented a situation even more problematic that for Curitiba, since, according to Correntino (2007), disorders were record by floods whose amount of rainfall was only of $41 \mathrm{~mm}$. This value corresponds to $94^{\text {th }}$ percentile well represented by R95p index. Also for this location the trend of index is positive, $3 \mathrm{~mm} /$ year. Observing the behavior of the indices more problems for the populations may be caused by R99p with a positive trend equal to $4.39 \mathrm{~mm} /$ year. For the extreme rains were recorded values quite high, and the maximum amount of a single day was $136.6 \mathrm{~mm}$, two times higher than the volume required to provoke inconvenience to the people.

Thus, associating the historic of flood events with the calculation of percentiles, for both municipalities, Curitiba and Goiania, it was possible to realize that the results are negative related to the possibilities of appearance of new cases of flooding in these towns. The problem becomes even more disturbing when the results of calculations of climate indices (Table 3) showed strong increasing trends in totals annual rainfall for these two municipalities. Considering Curitiba, this increase in annual rainfall is mainly conditioned to larger trends of rainfall events of greater intensity, above $95^{\text {th }}$ percentile. For Goiânia, the recorded intensities of rainfall were even higher, with increasing trends in volumes, above $99^{\text {th }}$ percentile and according to IBGE (2012), one should also consider that Curitiba $(1,776,761,000$ inhabitants) and Goiânia (1,333,767,000 inhabitants) are large municipalities, with very dense urban areas subject to a phenomenon known as "Heat Island" (Lombardo 1985), which causes increasing in temperatures and, consequently, enhancement in precipitation (Shepherd et al. 2002; Jauregui and Romales 1996; Hjemfelt 1982; Huff 1973).

\section{Conclusions}

A set of 32 daily cumulated precipitation series from meteorological stations, evenly distributed over the Paraná River Hydrographic Basin, was analyzed. Data underwent a quality control procedure in order to filter the influence of nonclimatic factors. Climatic indices demonstrated that in some regions the increasing trends in the amounts of rainfall were significant. While there is no spatial pattern in the distribution of these trends, it is clear that in a large part of the basin, there are positive trends in total annual rainfall, and this increase is correlated mainly to heavier rainfall.
The difference between the trends of increase and the reduction of rainfall is visible, since the values of each climate index clearly indicated the occurrence of larger amount of rain. Only at the extreme north of the basin that decreasing trends of rainfall are more pronounced. In other areas such as the center of the basin, there were weak trends of reduction in rainfall; however, it is difficult to affirm if there is a spatial distribution pattern since not all indices corroborate this statement.

These results are relevant for climate change impacts and the vulnerability assessment over Brazil. In fact, the correlation of percentile calculations with historical surveys of flood conducted to Curitiba and Goiânia demonstrated that it was common to record precipitation amount well above those that already caused damage for the population of both municipalities. If we consider that the increasing trends of heavy rainfall observed for these two towns were strong, the problems can become even more alarming. Moreover, both municipalities have intense urban and population growth, which can aggravate the situation, if there is no correct planning for such expansion.

On the other hand, we understand that despite the results that have clearly pointed to an increase of rainfall in the most part of the basin, this research needs to be improved since the lack of pluviometric stations in some regions may influence the identification of a spatial pattern of trends presented by the analyzed climate indices. Moreover, the data utilized presented lacks that may influence the analyses, and their improvement would be essential for the next investigations in order to confirm or not the obtained results. According to the INMET, which provided the data used in this research, most of the lacks in the data series for various stations were caused by problems in the database and not at the time of collecting the information for each climate variable. This problem is in the correction processes, which shall remedy such deficiencies or at least improve the parts of them. Thus, it is expected that soon, such information has already been available to society, and that other researches can be carried out with longer and higher quality data series, so that the results presented here can be compared ensuring greater reliability.

This work highlights the necessity to improve the analysis of Brazilian climate using a long and high quality dataset. An accurate climate analysis is an indispensable tool for the management and planning of Brazil, an economically emerging country.

Acknowledgments The authors would like to thank the Universidade Estadual Paulista, campus Rio Claro (Brazil) and the University of Torino (Italy), for allowing, by means of their professors and researchers, the initiative for the covenant between these two universities become a reality. The authors also thank the National Institute of MeteorologyINMET, a Brazilian government agency, for providing the pluviometric data used in this research and to the São Paulo Research FoundationFAPESP, an agency promoting scientific and technological research in 
Brazil, which is responsible for funding this research by means of a scholarship of encouragement to internships and research abroad.

\section{References}

Acquaotta F, Fratianni S (2013) Analysis on Long Precipitation Series in Piedmont (North-West Italy). Am J Clim Change 2:14-24. doi:10. 4236/ajcc.2013.21002

Acquaotta F, Fratianni S (2014) The importance of the quality and reliability of the historical time series for the study of climate change. Revista Brasileira de Climatologia 14:20-38

Acquaotta F, Fratianni S, Cassardo C, Cremonini R (2009) On the continuity and climatic variability of meteorological stations in Torino, Asti, Vercelli and Oropa. Meteorog Atmos Phys 103:279-287. doi: 10.1007/s00703-008-0333-4

Acquaotta F, Fratianni S, Garzena D (2014) Temperature changes in the North-Western Italian Alps from 1961 to 2010. Theor Appl Climatol. doi:10.1007/s00704-014-1316-7

Aguilar E, Peterson TC, Ramírez Obando P et al. (2005) Changes in precipitation and temperature extremes in Central America and Northern South America, 1961-2003. Journal of Geophysical Research, 110. doi: 10.1029/2005JD006119

Alexander LV, Zhang X, Peterson TC et al (2006) Global observed changes in daily climate extremes of temperature and precipitation. J Geophys Res 111:D05109. doi:10.1029/2005JD006290

Alexander LV, Tapper N, Zhang X et al (2009) Climate extremes: progress and future directions. Int J Climatol 29:317-319

ANA Agência Nacional de Águas (2013) http://www.ana.gov.br/ mapainicial/pgMapaL.asp

ANEEL Agência Nacional de Energia Elétrica (2013b). http://www. aneel.gov.br/area.cfm?id area $=110$

ANEEL AgênciaNacional de Energia Elétrica (2013a). http://www.aneel. gov.br/arquivos/PDF/atlas3ed.pdf

Barros VR, Doyle ME, Camilloni IA (2008) Precipitation trends in southeastern South America: relationship with ENSO phases and with low-level circulation. Theor Appl Climatol 93:19-33

Besselaar EJM, Klein Tank AMG, Buishand TA (2012) Trends in European precipitation extremes over 1951-2010. Int J Climatol $33: 2682-2689$

Boin MN (2000) Chuvas e Erosões do Oeste Paulista: uma análise climatológica aplicada. (Doutorado em Geociências e Meio Ambiente) - Instituto de Geociências e Ciências Exatas, Universidade Estadual Paulista "Júlio de Mesquita Filho", Rio Claro

Boulanger JP, Leloup J, Penalba O, Rusticucci M, Lafon F, Vargas W (2005) Observed Precipitation in the Paraná-Plata Hydrological Basin: long-term trends, extreme conditions and ENSO teleconnections. Clim Dyn 24:393-413

Camilloni IA, Barros VR (2003) Extreme discharge events in the Paraná River and their climate forcing. J Hydrol 278:94-106

Correntino M (2007) Características hidrográficas e dinâmica fluvial. In: revisão e detalhamento da Carta de Risco e Planejamento do Meio Físico do Município de Goiânia.

Cunico C, Glufke D, Kröker R, Rakssa M, Danni-Oliveira IM, Fraga N (2002) Episódios Chuvosos e seus Impactos em Curitiba/PR (1999/2000). Anais do V Simpósio Brasileiro de Climatologia Geográfica, Curitiba, pp 615-623

INMET Instituto Nacional de Meteorologia (2009) Normais Climatológicas do Brasil 1961-1990. http://www.inmet.gov.br/ portal/index.phpr=clima/normaisClimatologicas

INMET Instituto Nacional de Meteorologia (2013) Mapa da Rede de Estações. http://www.inmet.gov.br/portal/index.phpr=estacoes/ mapaEstacoes
Dufek AS (2008) Índices de Extremos Climáticos de Temperatura e Chuva na América do Sul: clima presente e validação do modelo RegCM3. Instituto de Astronomia, Geofísica e Ciências Atmosféricas, Departamento de Ciências Atmosféricas, Universidade de São Paulo.

Dufek AS, Ambrizzi T (2008) Precipitation variability in São Paulo state, Brazil. Theor Appl Climatol 93:167-178

Easterling DR, Meehl GA, Parmesan C, Changnon SA, Karl TR, Mearns LO (2000) Climate extremes: observations, modeling, and impacts. Atmos Sci 289:2068-2074

IBGE Instituto Brasileiro de Geografia e Estatística (2012) Estimativas populacionais para os municípios brasileiros em 01.07.2012. http:// www.ibge.gov.br/home/estatistica/populacao/estimativa2012/ estimativa dou.shtm

Figueiró AS, Coelho Netto AL (2011) Climatic variability and pluviometric trends in a humid tropical environment at Resende municipality — middle Paraíba do Sul river valley (Rio de JaneiroBrazil). Braz Geogr J: Geosci Humanities Res Medium 2:256-273

Fratianni S, Cassardo C, Cremonini R (2009) Climatic characterization of foehn episodes in Piedmont, Italy. Geografia Fisica e Dinamica del Quternaria 32:15-22

Fratianni S, Terzago S, Acquaotta F, Faletto M, Garzena D, Prola MC, Barbero S (2014) How snow and its physical properties change in a changing climate alpine context? Eng Geol Soc Territory 1:57-60. doi:10.1007/978-3-319-09300-0 11

Grimm AM, Barros VR, Doyle ME (2000) Climate variability in southern South America associated with El Niño and La Niña events. J Clim 13:35-58

Groisman PY, Karl TR, Easterling DR et al (1999) Changes in the probability of heavy the precipitation: important indicators of climatic change. Clim Chang 42:243-283

Groisman PY, Knight RW, Easterling DR, Karl TR, Hegerl GC, Razuvaev VN (2005) Trends in intense precipitation in the climate record. J Clim 18:1326-1350

Hack LP (2002) O clima urbano de Petrópolis - RJ - Análise dos impactos ambientais das chuvas de verão nas áreas de riscos e nas inundações. In: Sant'Anna Neto J L (Ed) Os climas das cidades brasileiras. Presidente Prudente, pp 89-114.

Haylock MR, Peterson TC, Alves LM et al (2006) Trends in total and extreme South American rainfall in 1960-2000 and links with sea surface temperature. J Clim 19:1490-1512

Hjemfelt MR (1982) Numerical simulation of the effects of St. Louis on mesoscale boundary-layer airflow and vertical air motion: simulations of urban vs. non-urban effects. J Appl Meteorol 21: 1239-1257

Huff FA (1973) Precipitation modification by major urban areas. Bull Am Meteorol Soc 54:1220-1232

IPCC, Intergovernmental Panel on Climate Change (1990) Climate Change, Working Group 1. Cambridge University Press

IPCC, Intergovernmental Panel on Climate Change (1992) Climate Change, The Supplementary Report. Cambridge University Press

IPCC, Intergovernmental Panel on Climate Change (2001) Impacts, adaptation, and vulnerability: contribution of working group II to the third assessment report. Press, Cambridge University

IPCC (2007) Climate change 2007. In: Solomon S, Qin D, Manning M, Chen Z, Marquis M, Averyt KB, Tignor M, Miller HL (eds) The physical science basis. Contribution of working group I to the fourth assessment report of the intergovernmental panel on climate change. Cambridge University Press, Cambridge, United Kingdomand New York, USA, p 996

IPCC (2013) Summary for policymakers. Climate change 2013. In: Stocker TF, Qin D, Plattner GK, Tignor M, Allen SK, Boschung J, Nauels A, Xia Y, Bex V, Midgley PM (eds) The physical science basis. Contribution of working group I to the fifth assessment report of the 
intergovernmental panel on climate change. Cambridge University Press, Cambridge, United Kingdom and New York, USA, p 29

Jauregui E, Romales E (1996) Urban effects on convective precipitation in Mexico City. Atmos Environ 30:3383-3389

Kalkstein LS, Smoyer KE (1993) The impact of climate change on human health: some international implications. Experientia 49:969 979

Karl TR, Nicholls N, Ghazi A (1999) CLIVAR/GCOS/WMO workshop on indices and indicators for climate extremes: workshop summary. Clim Chang 42:3-7

Klein Tank AMG, Können GP (2003) Trends in indices of daily temperature and precipitation extremes in Europe, 1946-99. J Clim 16: $3665-3680$

Klein Tank AMG, Wijngaard JB, Können GP et al (2002) Daily surface air temperature and precipitation dataset 1901-1999 for European Climate Assessment (ECA). Int J Climatol 22:1441-1453

Klein Tank AMG, Peterson TC, Quadir DA et al (2006) Changes in daily temperature and precipitation extremes in Central and South Asia. J Geophys Res 111, D16105. doi:10.1029/2005JD006316

Krepper CM, Zucarelli GV (2010) Climatology of water excesses and shortages in the La Plata Basin. Theor Appl Climatol 102:13-27

Kunkel KE, Pielke RA, Changnon SA (1999) Temporal fluctuations in weather and climate extremes that cause economic and human health impacts: a review. Bull Am Meteorol Soc 80:1077-1098

Liebmann B, Vera CS, Carvalho LMV, Camilloni IA, Hoerling MP, Allured D, Barros VR, Báez J, Bidegain M (2004) An observed trend in central South American precipitation. Am Meteorol Soc $17: 4357-4367$

Lombardo MA (1985) Ilhas de Calor nas Metrópoles: o exemplo de São Paulo. HUCITEC, São Paulo

Marengo JA (2008) Water and climate change. Estudos Avançados 22: 83-96, University of São Paulo. ISSN 0103-4014

Marengo JA, Jones R, Alves LM, Valverde MC (2009) Future change of temperature and precipitation extremes in South America as derived from the PRECIS regional climate modeling system. Int J Climatol 29:2241-2255

Meehl GA, Karl T, Easterling DR et al (2000) An introduction to trends in extreme weather and climate events: observations, socioeconomic impacts, terrestrial ecological impacts, and model projections. Bull Am Meteorol Soc 8:413-416

Mendonça F, Danni-Oliveira IM (2007) Climatologia: noções básicas e climas do Brasil. Oficina de Textos, São Paulo

Moberg A, Jones PD, Lister D et al. (2006) Indices for daily temperature and precipitation extremes in Europe analyzed for the period 19012000. J Geophys Res 111:D22106. doi:10.1029/2006JD007103

Monteiro CAF (1962) Da necessidade de um caráter genético à classificação climática (algumas considerações metodológicas a propósito do estudo do Brasil Meridional). Rev Geogr 31:29-44

Monteiro CAF (1963a) O clima da Região Sul. Geografia regional do Brasil—Região Sul. Rio de Janeiro 1:117-169

Monteiro CAF (1963b) Sobre a análise geográfica de sequências de cartas de tempo: pequeno ensaio metodológico sobre o estudo do clima no escopo da geografia. Rev Geogr 31:169-179

Monteiro CAF (1964) Sobre um índice de participação das massas de ar e suas possibilidades de aplicação à classificação climática. Rev Geogr 33:59-69

Monteiro CAF (1973) A dinâmica climática e as chuvas no Estado de São Paulo: estudo geográfico sob a forma de atlas. USP/Igeog, São Paulo

Monteiro CAF (2000) A Dinâmica Climática e as Chuvas no Estado de São Paulo. UNESP, Ageteo, 1 CD-ROM.

Mueller B, Seneviratne SI (2012) Hot days induced by precipitation deficits at the global scale. Proc Natl Acad Sci 109:12398-12403

Penalba OC, Robledo FA (2010) Spatial and temporal variability of the frequency of extreme daily rainfall regime in the La Plata basin during the 20th century. Climate Change 98:531-550
Peterson TC, Coauthors (2001) Report on the Activities of the Working Group on Climate Change Detection and Related Rapporteurs 1998-2001. WMO, Rep. WCDMP-47, WMO-TD 1071, Geneve, Switzerland

Sen Roy S, Rouault M (2013) Spatial patterns of seasonal scale trends in extreme hourly precipitation in South Africa. Appl Geogr 39:151157

Shepherd JM, Pierce H, Negri A (2002) Rainfall modification by major urban areas: observations from spaceborne rain radar on the TRMM satellite. J Appl Meteorol 41:689-701

Silva VBS, Berbery EH (2006) Intense rainfall events affecting the La Plata basin. J Hydrometeorol 7:769-787

Sneyers (1990) On the statistical analysis of series of observations. Geneva, WMO N 143, p 192.

Souza Filho EE, Stevaux JC, Jabur IC (1997) A história quaternária do rio Paraná. In: EDUEM (ed) A planície de inundação do alto rio Paraná. Maringá, 1, pp 46-62

Strahler AH (1951) Physical geography. John Wiley \& Sons, New York

Terzago S, Cassardo C, Cremonini R, Fratianni S (2010) Snow precipitation and snow cover climatic variability for the period 1971-2009 in the southwestern Italian alps: the 2008-2009 snow season case study. Water 2:773-787. doi:10.3390/w2040773

Terzago S, Cremonini R, Cassardo C, Fratianni S (2012) Analysis of snow precipitation during the period 2000-09 and evaluation of a snow cover algorithm in SW Italian alps. Geografia Fisica e Dinamica Quaternaria 35:91-99

Terzago S, Fratianni S, Cremonini R (2013) Winter precipitation in western Italian alps (1926-2010): trends and connections with the North Atlantic/Arctic oscillation. Meteorog Atmos Phys 119:125-136

Venema VKC, Mestre O, Aguilar E et al (2012) Benchmarking homogenization algorithms for monthly data. Clim Past 8:89-115. doi:10. 5194/cp8-89-2012

Vincent LA, Mekis E (2006) Changes in daily and extreme temperature and precipitation indices for Canada over the Twentieth Century. Atmosphere-ocean 44:177-193

Vincent LA, Peterson TC, Barros VR et al (2005) Observed trends in indices of daily temperature extremes in South America 1960 2000. J Clim 18:5011-5023

Walther GR, Post E, Convey P, Menze A et al (2002) Ecological responses to recent climate change. Nature 416:389-395. doi:10. $1038 / 416389^{\mathrm{a}}$

Wang W, Shao Q, Yang T et al (2013) Changes in daily temperature and precipitation extremes in the Yellow River basin, China. Stoch Environ Res Risk Assess 27:401-421. doi:10.1007/s00477-0120615-8

Yue S, Pilon P, Phinney B, Cavadias G (2002) The influence of autocorrelation on the ability to detect trend in hydrological series. Hydrol Process 16:1807-1829

Zandonadi L (2009) As Chuvas na Bacia do Paraná: aspectos temporais, espaciais e rítmicos. Instituto de Geociências e Ciências Exatas, Universidade Estadual Paulista "Júlio de Mesquita Filho", Rio Claro

Zandonadi L (2013) As chuvas na bacia hidrográfica do rio Paraná, Brasil: um estudo do ritmo climático e algumas considerações sobre a vazão hídrica. Tese de Doutorado - Universidade Estadual Paulista "Júlio de Mesquita Filho" Instituto de Geociencias e Ciencias Exatas

Zanella ME (2006) Inundações Urbanas em Curitiba/Pr: impactos, riscos e vulnerabilidade socioambiental no Bairro Cajuru. Tese de doutorado em Meio Ambiente e Desenvolvimento, Universidade Federal do Paraná.

Zavatini JA (1990) A Dinâmica Atmosférica e a Distribuição das Chuvas no Mato Grosso do Sul. Faculdade de Filosofia, Letras e Ciências Humanas, Universidade de São Paulo, São Paulo.

Zavattini JA (2009) As Chuvas e as Massas de Ar no Estado de Mato Grosso do Sul: estudo geográfico com vista à regionalização 
climática. São Paulo: Editora Cultura Acadêmica, Rio Claro: Editora Unesp. ISBN 978-85-7983-002-0

Zavattini JA, Boin MN (2013) Climatologia Geográfica: teoria e prática de pesquisa. Editora Alínea, Campinas. ISBN 978-85-7516611-6
Zhang X, Yang F (2004) RClimDex (1.0) User Guide. Climate Research Branch Environment Canada: Downs view, Ontario, Canada

Zhang X, Hegerl G, Zwiers FW, Kenyon J (2005) Avoiding inhomogeneity in percentile-based indices of temperature extremes. J Clim 18: $1641-1651$ 